\title{
PATCH REEF FORMATION ON THE BELIZE CARBONATE RAMP: A COMPARISON OF DEVELOPMENTAL STRATEGIES
}

BURKE, Collette D.*; MCHENRY, Theodore M.; MAZZULLO, Salvatore J.; and BISCHOFF, William D.; Dept. of Geology, Wichita State University, Wichita, Ks 67260-0027, U.S.A.

Patch reefs in Belize have formed on a partially enclosed, south-sloping carbonate ramp leeward of the barrier reef. Patch reefs from the northern and southern shelves on this ramp differ in age, coral composition and distribution. On the northern shelf, the patch reefs are young (less than 3,500 years), virtually monospecific, and display a random dispersion pattern. On the southern shelf, patch reefs are as much as 7,000 to 9,000 years old. They are more diverse and display coral zonation in response to differential wave action.

Although a multitude of environmental parameters affect the growth of reefs, these markedly dissimilar patch reefs in north and south Belize represent different developmental strategies as a consequence of the punctuated rate of Holocene sea level rise. Plots of Holocene sea level rise indicate that the initial inundation on the southern shelf of Belize occurred 9,000 to 10,000 yrs BP and rose rapidly (5-10 $\mathrm{m} / 1000 \mathrm{yr}$ ). As a result, southern patch reefs composed of fast growing corals (e.g. Acropora palmata and A. cervicornis) developed as "keep up" or "catch up" reefs, or to a lesser extent, drowned. In contrast, the northern shelf was inundated $4500 \mathrm{yr}$ $\mathrm{BP}$, and by this time, the rate of rise had decreased $(0.29 \mathrm{~m} / 1000 \mathrm{yr})$. As a consequence, slower growing corals (e.g. Montastrea annularis) predominate in the north and are able to proliferate because they developed under relatively static sea level conditions. These reefs reach sea level and develop laterally. New coral species begin to occupy the reefs when the heads become degraded and cavernous through bio- and physical erosion or split under the force of gravity. As a result of these differing developmental strategies to sea level rise a spectrum from north to south of "lateral expansion" patch reefs and "keep up" / "catch up" reefs occur on the Belize carbonate ramp. 